\title{
INTEGRASI PEMBELAJARAN KANJI \\ DENGAN PEMBELAJARAN SAKUBUN \\ UNTUK MENINGKATKAN KEMAMPUAN MENULIS
}

\section{Timur Sri Astami; Rosita Ningrum; Felicia Budihardja}

Japanese Department, Faculty of Humanities, Bina Nusantara University, Jln. Kemanggisan Ilir III No. 45, Kemanggisan-Palmerah, Jakarta Barat 11480

timur_astami@yahoo.com; ningrum@binus.edu; fbudihardja@binus.edu

\begin{abstract}
Research aims to find the influence of strategies used in intermediate kanji learning, i.e. in a more applicative class using kanji, on middle kanji and composition class (sakubun). Research viewed and compared the influence of students' mark in Intermediate Kanji with their mark in Sakubun. The questionnaire used in this research was the Strategy Inventory for Language Learning (SILL) consisting of 50 questions associated with types of strategy to learn kanji. The result obtained using T-test and correlation test was the students' mark in kanji affected their mark in Sakubun. The relationship is the higher mark in kanji, the higher mark in Sakubun. As a conclusion, student essay writing ability is affected by the numbers of kanji remembered and used by students.
\end{abstract}

Keywords: kanji, sakubun, SILL

\begin{abstract}
ABSTRAK
Tujuan dari penelitian ini adalah untuk mencari pengaruh strategi yang digunakan dalam pembelajaran kanji tingkat menengah, yakni pada kelas yang lebih aplikatif dalam menggunakan huruf kanji, pada kelas kanji menengah dan kelas mengarang (sakubun). Penelitian menghitung dan membandingkan pengaruh nilai Intermediate Kanji dengan nilai sakubun. Kuesioner yang digunakan dalam penelitian ini adalah Strategy Inventory for Language Learning (SILL) yang terdiri dari 50 pertanyaan terkait dengan jenis strategi dalam mempelajari kanji. Hasil yang diperoleh menggunakan uji T dan uji korelasi adalah terdapat hubungan nilai kanji dengan nilai sakubun. Makin tinggi nilai kanji, maka makin tinggi nilai sakubun. Simpulan dalam penelitian ini adalah kemampuan menulis karangan mahasiswa, selain faktor linguistik, juga dipengaruhi oleh faktor nonlinguistik, yaitu banyaknya huruf kanji yang diingat dan digunakan mahasiswa dalam menulis karangan.
\end{abstract}

Kata kunci: kanji, sakubun, SILL 


\section{PENDAHULUAN}

Dalam mempelajari Bahasa Jepang, ada empat kemampuan yang harus dipelajari, yaitu menulis, membaca, mendengar dan berbicara. Dalam menulis ada hal-hal yang harus dipelajari oleh pembelajar Bahasa Jepang. Yang pertama adalah menulis huruf hiragana yang digunakan untuk menulis huruf atau kata-kata dari Bahasa Jepang asli. Lalu ada huruf katakana yang digunakan untuk menulis kata-kata serapan dari bahasa asing. Selain itu, ada juga huruf kanji yang berasal dari China.

Sebelum pembelajar bahasa Jepang mempelajari huruf kanji, awalnya pembelajar mempelajari dahulu huruf hiragana dan katakana. Pada dasarnya cara baca huruf kanji ditulis dengan huruf hiragana dan katakana. Huruf hiragana digunakan untuk menulis cara baca kun (kunyomi) yang merupakan cara baca asli dari Jepang. Sedangkan huruf katakana digunakan untuk menulis cara baca on (onyomi) yang merupakan cara baca asli dari huruf China yang pelafalannya sudah disesuaikan dengan lidah orang Jepang.

Pembelajaran huruf kanji di jurusan Sastra Jepang, Universitas Bina Nusantara terbagi menjadi enam semester. Semester satu sampai semester empat merupakan pembelajaran kanji tingkat dasar, semester lima dan enam merupakan pembelajaran kanji untuk tingkat menengah. Pada pembelajaran kanji tingkat dasar, pembelajar harus mempelajari kurang lebih 500 huruf kanji tingkat dasar (Kano, et al., 2010:198-200). Hal ini cukup menyulitkan para pembelajar terutama pembelajar yang tidak pernah mempelajari huruf kanji sebelumnya, atau dengan kata lain pembelajar yang berlatar belakang non kanji. Karena selain pembelajar harus mempelajari cara baca kanji tersebut baik secara kunyomi maupun onyomi, pembelajar juga harus mempelajari arti dari kanji dan kanji gabungan dari kanji dasar tersebut.

Sedangkan pada pembelajaran kanji tingkat menengah, kesulitan yang dialami pembelajar adalah pada saat pembelajar harus mempelajari kembali huruf kanji tingkat dasar agar tidak lupa. Selain itu, pembelajar harus pula mempelajari huruf kanji baru yang terdapat pada kanji tingkat menengah. Untuk itulah variasi pembelajaran pada mata kuliah kanji diperlukan, khususnya kanji tingkat menengah yang memiliki variasi kanji jukugo (Kano, et al., 1993:5).

Selanjutnya para pembelajar non-kanji, menurut Douglas (2010) dalam penelitiannya di Amerika, menunjukkan bahwa kecenderungan responden menerapkan kosakata yang digunakan dalam berbicara ketika diterapkan pada kosakata yang digunakan dalam tulisan--baik berupa huruf kana maupun kanji--lebih sedikit. Selain itu, masing-masing kemampuan menulis dan membaca huruf kanji antara pembelajar terdapat kesenjangan antara yang bisa dan tidak bisa menulis maupun membaca huruf kanji.

Pembelajar semester enam selain mendapatkan mata kuliah Intermediate Kanji 2, pembelajar juga mendapatkan mata kuliah Mengarang 2 (Sakubun 2). Pada mata kuliah ini, pembelajar membuat karangan sesuai dengan tema yang telah ditentukan oleh pengajar. Tema yang ditentukan beragam dan pembelajar mengembangkan tema tersebut menjadi satu karangan. Ada beberapa kesulitan yang dialami pembelajar dalam mata kuliah mengarang ini, di antaranya kesulitan menempatkan tata bahasa yang tepat dalam karangan. Selain kesulitan dalam tata bahasa, pembelajar juga mengalami kesulitan dalam menempatkan kanji dalam dalam kalimat. Beberapa kesulitan tersebut di antaranya adalah pembelajar sering salah menempatkan huruf kanji yang tepat ke dalam kalimat.

Pembelajar yang memiliki kemampuan bahasa Jepang yang baik, kadang-kadang menulis kata-kata yang seharusnya tidak ditulis dengan huruf kanji, tetapi ditulis dengan huruf kanji. Sedangkan pembelajar yang memiliki kemampuan bahasa Jepang yang kurang baik, kadangkadang tidak menggunakan kanji-kanji tingkat dasar dan menengah dalam kalimat. Hal inilah yang menjadi masalah karena pembelajar kurang dapat menggunakan huruf kanji secara tepat dalam karangan.

\section{METODE}

Penelitian ini adalah penggabungan pendekatan kualitatif dan kuantitatif. Secara kualitatif diambil untuk pendeskripsian yang penuh tentang pendekatan komunikatif. Sedangkan secara kuantitatif data yang diperoleh dihitung secara statistik guna mengukurpengaruh nilai kanji pada keberhasilan menulis karangan bahasa Jepang pada mahasiswa. Rumus yang dipakai adalah uji $\mathrm{T}$ paired samples untuk melihat peningkatan nilai ratarata yang menunjukkan adanya peningkatan kemampuan penerapan kanji pada mata kuliah mengarang atau sakubun. Selain itu nilai sakubun dan kanji juga dianalisis menggunakan uji korelasi. Uji korelasi digunakan untuk menguji tentang ada tidaknya hubungan antarvariabel satu dengan lainnya serta menegaskan hubungan kemampuan kanji dengan kemampuan mengarang mahasiswa.

Instrumen lain yang digunakan adalah kuesioner. Kuesioner yang digunakan dalam penelitian ini adalah strategy inventory for language learning (SILL) dikembangkan oleh Oxford (1994). SILL terdiri dari 50 pertanyaan terkait dengan jenis strategi mempelajari kanji, yakni berupa strategi langsung terdiri dari memori, kognitif, dan kompensasi; sedangkan strategi tidak langsung berupa metakognitif, afektif, dan sosial (Oxford 1994:293-300).

Lebih lanjut, Bourke dalam Musashi (2006) menambahkan SILK (Strategy Inventory Learning Kanji) yang merujuk pada SILL. Ia menyebutkan bahwa SILK terbagi menjadi 2, yakni strategi langsung dan tidak langsung. Strategi langsung ditinjau secara fonetik, frekuensi, struktur, respons, pengalaman, bushu, story, kakijun, urutan, visualisasi, self monitor, kompensasi. Sedangkan strategi tidak langsung berupa perencanaan pembelajaran, evaluasi pembelajaran, dan pembelajaran kooperatif.

\section{HASIL DAN PEMBAHASAN}

Penelitian memaparkan analisis data yang diperoleh, yaitu untuk mengetahui sejauh mana pembelajar dapat mengaplikasikan huruf kanji yang telah dipelajari dalam mata kuliah Intermediate Kanji 2 ke mata kuliah Mengarang 2. Khususnya, aplikasi huruf 
kanji yang berkaitan dengan strategi yang digunakan oleh respoden dalam mempelajari kanji. Serta, bagaimana tanggapan responden terhadap proses aplikasi kanji dalam pembelajaran mengarang.

Untuk mengetahui adanya penggunaan kanji yang sesuai dan terintegrasi pada mata kuliah kanji ke dalam karangan, maka perlu diketahui kemampuan awal mereka. Untuk mengetahui kemampuan awal mahasiswa, mereka diberi tes awal (pretest). Setelah seluruh pembelajaran selesai dilaksanakan, sampel diberikan tes akhir (posttest). Pemberian tes akhir diberikan untuk mengetahui peningkatan kemampuan menulis kanji yang diintegrasikan ke dalam karangan bahasa Jepang pada mahasiswa.

\section{Hasil Analisis Nilai Kanji}

Untuk mengukur penerapan kanji di dalam mata kuliah mengarang bahasa Jepang, peneliti mengambil hasil tes sebelum dan sesudah sesi pembelajaran selama satu semester. Hasil pretest dan posttest tersebut dapat dilihat pada Tabel 1 .

Tabel 1 Hasil Pretest dan Posttest Kanji

\begin{tabular}{|c|c|c|c|}
\hline No & Nama Mahasiswa & Pretest & Posttest \\
\hline 1 & $\mathrm{R} 1$ & 65 & 85 \\
\hline 2 & R2 & 55 & 70 \\
\hline 3 & $\mathrm{R} 3$ & 65 & 83 \\
\hline 4 & R4 & 68 & 98 \\
\hline 5 & R5 & 65 & 65 \\
\hline 6 & R6 & 95 & 100 \\
\hline 7 & R7 & 95 & 100 \\
\hline 8 & $\mathrm{R} 8$ & 58 & 75 \\
\hline 9 & R9 & 50 & 58 \\
\hline 10 & $\mathrm{R} 10$ & 83 & 90 \\
\hline 11 & R11 & 55 & 73 \\
\hline 12 & $\mathrm{R} 12$ & 68 & 65 \\
\hline 13 & R13 & 55 & 63 \\
\hline 14 & R14 & 63 & 88 \\
\hline 15 & $\mathrm{R} 15$ & 68 & 83 \\
\hline 16 & R16 & 55 & 65 \\
\hline 17 & R17 & 80 & 85 \\
\hline 18 & R18 & 48 & 65 \\
\hline 19 & R19 & 98 & 98 \\
\hline 20 & $\mathrm{R} 20$ & 83 & 98 \\
\hline 21 & $\mathrm{R} 21$ & 30 & 43 \\
\hline 22 & R22 & 73 & 78 \\
\hline 23 & $\mathrm{R} 23$ & 63 & 56 \\
\hline 24 & R24 & 93 & 85 \\
\hline 25 & R25 & 55 & 78 \\
\hline 26 & R26 & 65 & 73 \\
\hline 27 & R27 & 65 & 75 \\
\hline 28 & R28 & 58 & 75 \\
\hline 29 & R29 & 60 & 73 \\
\hline 30 & R30 & 68 & 80 \\
\hline
\end{tabular}

Tabel 1 Hasil Pretest dan Posttest Kanji (lanjutan)

\begin{tabular}{llcc}
\hline No & Nama Mahasiswa & Pretest & Posttest \\
\hline 31 & R31 & 78 & 93 \\
32 & R32 & 60 & 73 \\
33 & R33 & 53 & 75 \\
34 & R34 & 83 & 98 \\
35 & R35 & 85 & 88 \\
36 & R36 & 48 & 60 \\
37 & R37 & 70 & 90 \\
\hline
\end{tabular}

Data hasil pretest menunjukkan nilai terendah 30 dan nilai tertinggi 98. Rata-rata nilai tes awal (pretest) adalah 67.0 dengan standar deviasi 15,13. Sedangkan untuk posttest, responden menunjukkan nilai terendah 43 dan nilai tertinggi 98 . Untuk rerata nilai posttest adalah 78,37 dengan standar deviasi adalah 13,95. (Gambar 1)

Paired Samples Statistics

\begin{tabular}{|ll|r|r|r|c|}
\hline & & Mean & \multicolumn{1}{|c|}{ N } & Std. Deviation & $\begin{array}{c}\text { Std. Error } \\
\text { Mean }\end{array}$ \\
\hline Pair 1 & pre & 67.0000 & 37 & 15.13275 & 2.48781 \\
& post & 78.3784 & 37 & 13.95499 & 2.29419 \\
\hline
\end{tabular}

Gambar 1 Hasil Pretest dan Postest Kanji

Hal tersebut menandakan kemampuan kanji pada responden tidak seragam. Kenaikan nilai yang cukup baik terlihat dari nilai posttest.

\section{Hasil Analisis Nilai Mengarang (Sakubun)}

Untuk melihat kemampuan mengarang bahasa Jepang, peneliti mengambil nilai pretest dan posttest. Makin baik nilai di mata kuliah mengarang atau sakubun, diasumsikan makin banyak kanji-kanji yang diterapkan mahasiswa. Hasil pretest dan posttest tersebut dapat dilihat pada Tabel 2.

Tabel 2 Hasil Pretest dan Postest Sakubun

\begin{tabular}{ccc}
\hline Nama Mahasiswa & Pre Test & Post Test \\
\hline R1 & 68 & 65 \\
R2 & 94 & 98 \\
R3 & 79 & 82 \\
R4 & 79 & 76 \\
R5 & 94 & 94 \\
R6 & 86 & 96 \\
R7 & 96 & 98 \\
R8 & 86 & 86 \\
R9 & 80 & 62 \\
R10 & 87 & 88 \\
R11 & 83 & 82 \\
R12 & 87 & 85 \\
\hline
\end{tabular}


Tabel 2 Hasil Pretest dan Postest Sakubun (lanjutan)

\begin{tabular}{lcc}
\hline Nama Mahasiswa & Pre Test & Post Test \\
\hline R13 & 67 & 83 \\
R14 & 67 & 86 \\
R15 & 88 & 89 \\
R16 & 75 & 76 \\
R17 & 96 & 99 \\
R18 & 78 & 90 \\
R19 & 85 & 85 \\
R20 & 81 & 87 \\
R21 & 67 & 66 \\
R22 & 87 & 100 \\
R23 & 82 & 98 \\
R24 & 93 & 93 \\
R25 & 90 & 93 \\
R26 & 76 & 75 \\
R27 & 90 & 90 \\
R28 & 70 & 64 \\
R29 & 73 & 74 \\
R30 & 78 & 74 \\
R31 & 98 & 100 \\
R32 & 99 & 93 \\
R33 & 96 & 74 \\
R34 & 98 & 97 \\
R35 & 99 \\
R36 & 98 \\
R37 & 99 \\
\hline & & \\
\hline
\end{tabular}

Data hasil pretest menunjukkan nilai terendah 67 dan nilai tertinggi 98. Rata-rata nilai tes awal (pretest) adalah 83.64 dengan standar deviasi 9,23. Sedangkan untuk posttest, responden menunjukkan nilai terendah 62 dan nilai tertinggi 100. Untuk rata-rata nilai posttest adalah 84,89 dengan standar deviasi adalah 11,56. (Gambar 2)

\begin{tabular}{|c|c|c|c|c|c|}
\hline \multicolumn{6}{|c|}{ Paired Samples Statistics } \\
\hline & & Mean & $\mathrm{N}$ & Std. Deviation & $\begin{array}{l}\text { Std. Error } \\
\text { Mean }\end{array}$ \\
\hline \multirow[t]{2}{*}{ Pair 1} & pre & 83.6486 & 37 & 9.23224 & 1.51777 \\
\hline & post & 84.8919 & 37 & 11.56572 & 1.90139 \\
\hline
\end{tabular}

Gambar 2 Hasil Pretest dan Posttest Sakubun

Berdasarkan hal tersebut, kemampuan mengarang mahasiswa mengasumsikan kemampuan penggunaan kanji.

\section{Uji T-Test pada Kelas Kanji}

Peningkatan nilai rata-rata menunjukkan adanya peningkatan kemampuan mahasiswa dalam menerapkan penggunaan kanji dalam tugas mandiri di kelas kanji maupun di kelas mengarang. Adapun korelasi kemampuan penggunaan kanji antara dua buah sampel pretest dan posttest ditunjukkan dengan nilai koefisien korelasi $\mathrm{r}=$ 0,829 dengan nilai signifikansi korelasi sebesar $0,000<\alpha$ $=0,05$ seperti pada Gambar 3 berikut. Ini berarti korelasi antara nilai pretest dan postest menunjukkan korelasi positif yang signifikan.

Paired Samples Correlations
\begin{tabular}{|r|r|r|c|}
\hline & N & Correlation & Sig. \\
\hline Pair 1 pre \& post & 37 & .829 & .000 \\
\hline
\end{tabular}
Gambar 3 Hasil Paired Samples Correlations
dari Hasil Pretest dan Posttest Kanji

Hasil tersebut diperkuat dengan pengujian hipotesis mengenai perbedaan yang kentara dan signifikan pada nilai posttest daripada nilai pretest. Hipotesis ini adalah sebagai berikut:

$\mathrm{H} 0=$ kemampuan kanji tidak berpengaruh pada hasil belajar bahasa Jepang;

$\mathrm{H} 1$ = kemampuan kanji berpengaruh pada hasil belajar bahasa Jepang.

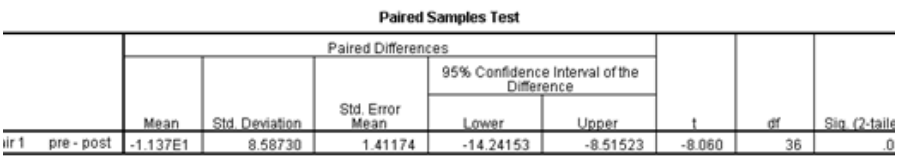

Gambar 4 Uji Signifikansi Nilai Rata-rata Pretest dan Posttest

Pengujian hipotesis memperlihatkan hasil seperti pada Gambar 4, yakni dengan nilai-p $=0.000$. Karena nilai-p $<0,05$, H0 ditolak. Atau dengan kata lain, hasil posttest lebih tinggi secara signifikan dibandingkan hasil pretest.

\section{Uji T-Test pada Kelas Sakubun}

Peningkatan nilai rata-rata menunjukkan adanya peningkatan kemampuan penerapan kanji pada mata kuliah mengarang atau sakubun dilihat dari nilai pre- dan posttest. Adapun korelasi antara dua buah sampel pretest dan posttest ditunjukkan dengan nilai koefisien korelasi $\mathrm{r}$ $=0,708$ dengan nilai signifikansi korelasi sebesar $0,000<$ $\alpha=0,05$ seperti pada Gambar 5 .

Paired Samples Correlations

\begin{tabular}{|l|r|r|r|}
\hline & \multicolumn{1}{|c|}{$\mathrm{N}$} & Correlation & $\mathrm{Sig}$ \\
\hline Pair 1 pre \& post & 37 & .708 & .000 \\
\hline
\end{tabular}

Gambar 5 Hasil Paired Samples Correlations dari Hasil Pretest dan Posttest Sakubun 
Ini berarti korelasi antara nilai pretest dan posttest menunjukkan korelasi positif yang signifikan. Hasil pengujian diperkuat dengan pengujian hipotesis mengenai perbedaan yang kentara dan signifikan pada nilai posttest daripada nilai pretest. Hipotesis ini adalah sebagai berikut: $\mathrm{H} 0=$ kemampuan kanji tidak berpengaruh pada hasil mengarang bahasa Jepang

$\mathrm{H} 1$ = kemampuan kanji berpengaruh pada hasil mengarang bahasa Jepang

Paired Samples Test

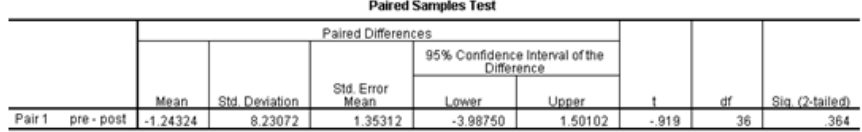

Gambar 6 Uji Signifikansi Nilai Rata-rata Pretest dan Postest

Pengujian hipotesis memperlihatkan hasil seperti pada Gambar 6, yakni dengan nilai-p $=0.001$. Karena nilai-p $<0,05$, H0 ditolak. Atau dengan kata lain, hasil posttest lebih tinggi secara signifikan dibandingkan hasil pretest.

\section{Uji Korelasi antara Nilai Kanji dan Sakubun}

Uji korelasi digunakan untuk menguji tentang ada tidaknya hubungan antar variabel satu dengan lainnya. Uji ini untuk menegaskan hubungan kemampuan kanji dengan kemampuan mengarang mahasiswa. Di bawah ini adalah hasil antara nilai posttest kanji dengan nilai posttest sakubun.

\begin{tabular}{|c|c|r|r|}
\hline & Descriptive Statistics \\
\hline & Mean & Std. Deviation & N \\
\hline post1 & 78.3784 & 13.95499 & 37 \\
post2 & 84.8919 & 11.56572 & 37 \\
\hline
\end{tabular}

\begin{tabular}{|ll|r|r|}
\multicolumn{4}{|c|}{ Correlations } \\
\hline \multicolumn{1}{|c|}{} & \multicolumn{1}{|c|}{ post1 } & \multicolumn{1}{c|}{ post2 } \\
\hline post1 & Pearson Correlation & 1 & $.398^{\circ}$ \\
& Sig. (2-tailed) & & .015 \\
& N & 37 & 37 \\
\hline post2 & Pearson Correlation & $.398^{\prime}$ & 1 \\
& Sig. (2-tailed) & .015 & \\
N & 37 & 37 \\
\hline
\end{tabular}

*. Correlation is significant at the 0.05 level (2-tailed).

Gambar 7 Uji korelasi Nilai Kanji dan Sakubun

Berdasarkan hasil uji korelasi nilai kanji dan sakubun (Gambar 7), diketahui rata-rata nilai posttest kanji adalah sebesar 78.37 dengan standar deviasi 13.95. Kemudian, rata-rata nilai posttest sakubun adalah 84.89 dengan standar deviasi 11.56.
Hipotesis:

$\mathrm{H} 0$ = Ada hubungan nilai posttest kanji dengan nilai posttest sakubun;

$\mathrm{H} 1$ = Tidak hubungan nilai posttest kanji dengan nilai posttest sakubun.

Berdasarkan uji korelasi terdapat hubungan nilai posttest kanji dengan nilai posttest sakubun. Besarnya nilai hubungan tersebut sebesar negatif 0,398. Sifat korelasi negatif menunjukkan makin rendah nilai posttest kanji, maka makin rendah nilai posttest sakubun. Sebaliknya, makin tinggi nilai posttest kanji, maka makin tinggi nilai posttest sakubun. Nilai signifikansi r-hitung sebesar 0,015, berarti hubungan tersebut siginifikan atau diterima pada probabilitas 5\%.

\section{Hasil Analisis Angket}

Dalam kaitannya dengan materi pada Intermediate Kanji, berikut jawaban responden yang berkaitan dengan strategi belajar yang digunakan oleh responden. Dalam mempelajari Intermediate Kanji, sebagian besar responden (90\%) menjawab kadang-kadang mengasosiasikan huruf kanji dengan kelompok yang sama artinya dengan huruf kanji yang sudah dipelajari sebelumnya (Gambar 8).

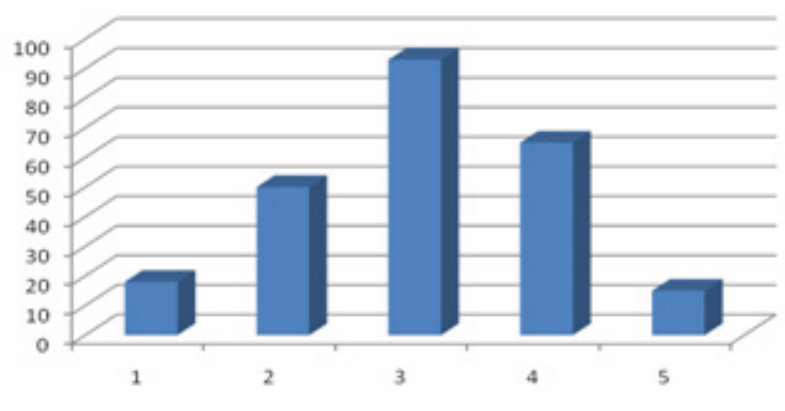

Gambar 8 Jawaban Responden Belajar Kanji dengan Asosiasi

Kemudian, sebagian besar responden (50\%) menjawab kadang-kadang mempelajari huruf kanji dengan membuat cerita berdasarkan buku referensi tentang pelajaran huruf kanji dan huruf kanji yang diceritakan oleh pengajar di kelas (Gambar 9).

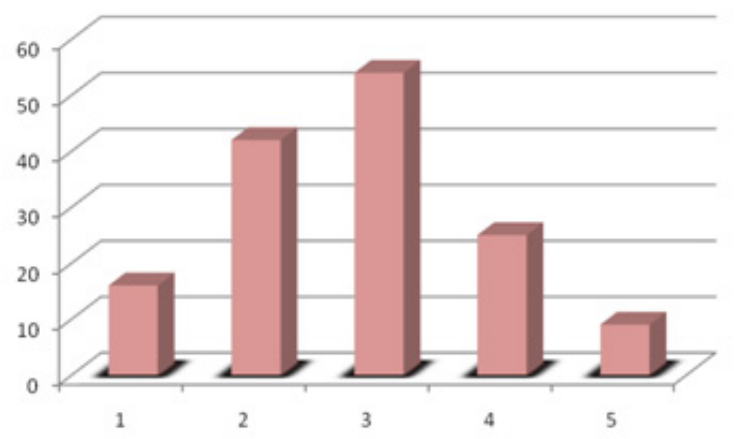

Gambar 9 Jawaban Responden Belajar Kanji dengan Cerita 
Lalu sebagian besar responden (49\%) menjawab kadang-kadang mempelajari huruf kanji dengan menghubungkan kanji dengan arti dari karakter dasar kanji, dengan mengingat karakter dasar kanji dan mengelompokkan kanji yang mempunyai karakter dasar yang sama (Gambar 10).

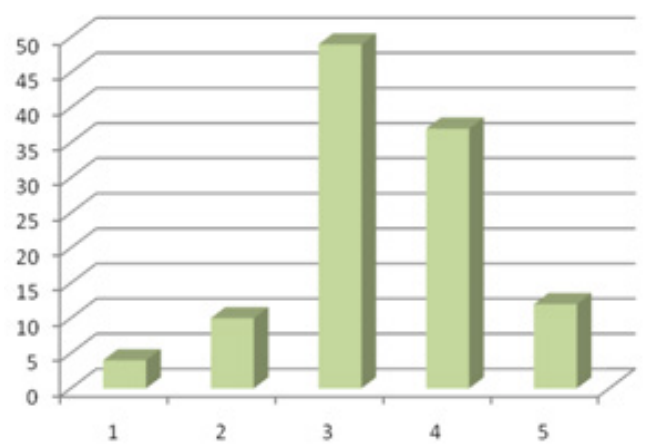

Gambar 10 Jawaban Responden Belajar Kanji Berdasarkan Karakter Dasar Huruf Kanji

Lebih lanjut, dalam kaitannya dengan strategi mengatur belajar, Gambar 11 menunjukkan jawaban responden yang berkaitan dengan strategi mengatur belajar yang digunakan oleh responden. Sebanyak 44\% responden kadang-kadang mengalokasikan waktu untuk mengatur jam belajar, khususnya belajar kanji tiap hari/ minggu. Sejumah 20\% responden menyatakan cukup sering untuk mengatur jam belajar ketika mempelajari kanji.

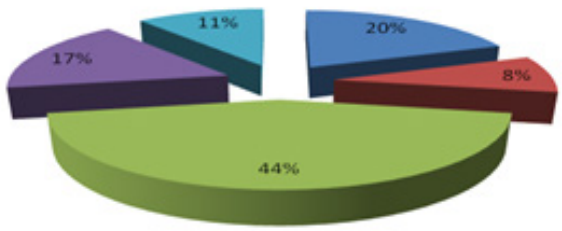

Gambar 11 Jawaban Responden dalam Mengatur Waktu Belajar

Kemudian sebanyak $32 \%$ responden kadangkadang menggunakan kartu kanji dalam mempelajari kanji. Sementara $26 \%$ responden menyatakan cukup sering menggunakan kartu kanji dalam mempelajari kanji. (Gambar 12)

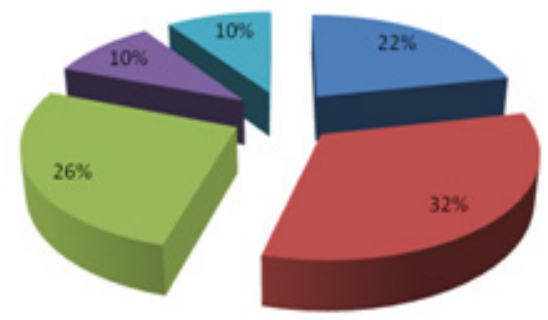

Gambar 12 Jawaban Responden dalam Menggunakan Kartu Kanji
Lalu sebanyak 33\% responden kadang-kadang menggunakan komputer dalam mempelajari kanji khususnya yang berkaitan dengan games kanji. Sementara $33 \%$ responden menyatakan cukup sering menggunakan komputer dalam mempelajari kanji, khususnya yang berkaitan dengan games kanji.

\section{SIMPULAN}

Berdasarkan hasil olahan data dan hasil interpretasi data, penelitian dapat disimpulkan sebagai berikut. Pertama, pembelajaran mengarang berkaitan dengan proses pemerolehan pengetahuan yang diperolehnya berupa kosakata, kalimat, hingga tata bahasa. Makin baik isi karangan tentunya akan banyak mengunakan kosakata, kalimat, hingga tata bahasa sesuai dengan tema karangan yang diminta. Kedua, pada pembelajaran mengarang (sakubun) tentu menggunakan huruf hiragana, katakana, dan kanji pada karangan yang dibuat. Ketiga, pembelajar dapat mengaplikasikan huruf kanji yang telah dipelajari dalam mata kuliah Intermediate Kanji 2 dalam mata kuliah Mengarang 2. Keempat, mata kuliah Intermediate Kanji akan lebih bisa berguna secara maksimal untuk pembelajar apabila dihubungkan dengan mata kuliah lain, dalam hal ini mata kuliah Mengarang (Sakubun). Kelima, berdasarkan hasil analisis nilai pre- dan posttest terdapat korelasi yang signifikan dan erat bahwa pengetahuan kanji memengaruhi kemampuan mengarang bahasa Jepang pada mahasiswa.

\section{Saran}

Beberapa saran yang ingin peneliti sampaikan kepada pihak-pihak yang berhubungan secara langsung atau tidak langsung pada hasil penelitian ini di antaranya perlunya integrasi pada mata kuliah kanji dan mengarang terutama dalam pemilihan tema, kosakata kanji, dan penyajian materi atau buku dan selain mata kuliah kanji, yakni kemampuan mengarang mahasiswa menarik untuk diuji dengan menghubungkan pada kemampuan penggunaan tata bahasa Jepang dalam mengarang (sakubun).

\section{DAFTAR PUSTAKA}

Douglas, M. O. (2010). Analysis of kanji ability of heritage learners of Japanese. JHL Journal. Available at http://www.aatj.org/resources/sig/ heritage/ejournal/vol3.pdf

Kano, C., Shimizu, Y., Takenaka, H., Ishii, E., \& Akustsu, S. (1993). Intermediate Kanji Book I. Tokyo: Bonjinsha.

Kano, C., Takenaka, H., Ishii, E., \& Shimizu, Y. (2010). Basic Kanji Book I. Tokyo: Bonjinsha.

Musashi, Y. (2006). J S L 唱童に対する漢字指導研 究一日本語能力の向上を目指した内容重視の アプローチを通じてーAvailable at http://www.gsjal.jp/kawakami/dat/master05d.pdf

Oxford, R. (1994). Gengogaku Sutorateji. Tokyo: Bojinsha. 